\title{
NUTRITIONAL STATUS OF CHILDREN OF URBAN LOW-INCOME COMMUNITIES, BRAZIL (1986)*
}

\author{
Maria Carmen Bisi Molina ** \\ Rainer Gross *** \\ Bernd Schell ${ }^{* * *}$ \\ Maria Antonia Cuelho Leão**** \\ Ulrike Strack***** \\ Brunke Brunken ${ }^{* * * * *}$
}

MOLINA, M.C.B. et al. Nutritional status of children of urban low-income communities, Brazil

(1986). Rev.Saúde públ., S. Paulo, 23:89-97,1989.

ABSTRACT: During the second half of 1986 the health and nutritional status of 254 children aged up to six years was studied, as well as the socio-economic situation of their parents in two favelas (shantytowns) in Belo Horizonte, Brazil. The nutritional status of the children was characterized by stunting ( $Z$-score: $20.1 \%<-2$ ) but not by wasting ( $\mathrm{Z}$-score: $3.7 \%<-2$ ). Consideration was also given to how far stunting was caused by high morbidity such as acute respiratory infections (point prevalence: $38.5 \%$ ), diarrheal diseases (point prevalence: $11.5 \%$ ) and parasitosis (point prevalence: $70.3 \%$ ). Furthermore, anemia (point prevalence: $29.7 \%$ ) appeared as another health problem. The most important determinant of anthropometric indices turned out to be the mother's schooling. From the present data it can be hypothesized that the nutritional status of the children was limited less by the lack of food than by their poor health status.

KEYWORDS: Nutritional status. Health status. Anthropometry. Growth. Morbidity.

\section{INTRODUCTION}

The identification and investigation of nutritional problems in developing countries have been carried out mainly in rural areas 12. Demographic projects, however, show that $50 \%$ of the world's population will be living in urban or peri-urban areas by the year 2000 . This trend of urbanization is especially dramatic in Latin America, where by the turn of this millennium about $80 \%$ of the population will live in urban areas. A new type of city with more than 20 million inhabitants will arise in many countries ${ }^{3}$. Epidemiologically, these metropolises will have new determining factors in the health and nutrition of the population that will completely change the profile of problems ${ }^{9}$. Up until now, we have only scant knowledge about the prevalence and causality of nutritional and health problems in urban areas. The lack of such knowl- edge presents an obstacle for implementation of appropriate solutions in the planning of third world cities. Studies of the nutritional and health status of the urban population should facilitate better understandig of the causality of nutritional and health problems in the complex urban system.

Through an interdiscriplinary project involving the government of Brazil and the Deutsche Gesellschaft für Technisch Zusammenarbeit (GTZ) GmbH (German Agency for Technical Cooperation), a nutritional component was integrated into an urbanization project in Belo Horizonte. This is a city with 2.4 million people in its metropolitan area and is the capital of Minas $\mathrm{Ge}$ rais in the South-Central area of Brazil. Belo Horizonte is the third largest city in Brazil.

The objective of this study was to diagnose and analyze the magnitude and causality of the
Supported by the Federal Ministry for Economic Cooperation of the Federal Republic of Germany. Instituto de Nutrição do Centro de Ciências da Saúde da Universidade Federal do Rio de Janeiro - 21941 - Rio de Janeiro, RJ - Brasil.

Deutsche Gesellschaft für Technische Zusammenarbeit (GTZ) GmbH, Section 162 - P.O. Box 5180 - D-6236 Eschborn, Federal Republic of Germany.

Secretaria de Saúde da Prefeitura Municipal de Belo Horizonte - Rua Tupis, 149 - 30190 - Belo Horizonte, MG - Brazil.

Deutsche Gesellschaft für Technische Zusammenarbeit (GTZ) c/o Secretaria de Estado do Trabalho e Ação Social (SETAS) Rua Gentios, 75 - $8^{\circ}$ andar - 30380 - Belo Horizonte, MG - Brazil. 
nutritional problems of children aged up to six years. This age group had been hypothesized as the most vulnerable group in the urban area. In a separate paper, the outcome of the two most important nutritional intervention structures on the above mentioned age-group - the health posts and creches (day care centers) - will be evaluated prior to the integration of the nutritional component. In a further paper the problems and interventions related to diarrhea and parasitism will be described. The three papers combined are intended to aid the horizontal planning of nutritional and health interventions.

\section{METHODS}

\section{Population studied}

The State Secretary of Employment and Social Action (SETAS) together with GTZ are carrying out an urbanization project, designed to improve the basic infrastructure of the two deprived areas. Both communities are located in the southern center of the city. They are $4 \mathrm{Km}$ apart and are subdivided into several favelas (shantytowns). At the time of the study, approximately 50 thousand inhabitants were living in an area of 108.0 ha in "Alto da Serra", consisting of the "favelas" (shantytowns) "Vila de Nossa Senhora da Conceição", "Vila de Santana do Cafezal", "Nossa Senhora de Fátima" and "Marçola". In the second conurbation of "Barragem de Santa Lúcia" and "Vila Rita de Cássia", an area of 43.7 ha was occupied by 25 thousand inhabitants. Three health posts under the Municipal Secretary of Health, three creches and three schools were run in Serra. Two health posts and schools and three creches were located in "Sta. Lúcia/Vila Rita".

Based on a map obtained by SETAS the study area was divided into clusters with six buildings in each cluster. After a computerized random selection of the cluster to be studied, a randomized ranking of the six houses was undertaken. This method enabled alternatives in cases where there was no child under six vaars in the first; buildings selected. The objective and the methodology of the survey was discussed at several meetings and approved by public authorities, such as SETAS, the Secretary of Health and health post personnel, as well as by the community. Data collection was always taken by the same nutritionist (a co-author of the study) with the assistance of three social workers and six auxiliary health personnel from the health posts in the communities. The auxiliary personnel had been trained by the nutritionist. Eighty households in Serra and 60 households in "Sta. Lúcia/ Vila Rita", all with at least one child of up to six years of age, were visited during September and October 1986.

\section{Anthropometric data}

All anthropometic data were laken according to the WHO recommendation 19 . Children were weighed using an electronic scale (SECA 770 ) calibrated in increments of $100 \mathrm{~g}$. They were weighed lightly clothed and without shoes. If the children were too young to stand on the scale the mother was asked to take her childed in her arms and they were weighed together. The scale permits an automatic zero setting with a person already standing on it. This procedure enabled a rapid, and for the babies less traumatizing, weighing procedure, since there was no need to separate the infant from its mother.

The height of the children of under two years was measured in a specially prepared baby meter box. With the help of the auxiliary personnel, the heels of the child were held against the fixed end of the box. Then the headboard at the other end was gently moved against the child's head and the supine length was read from the edge of the headboard which moved over the tape measure. The heights of the children who could stand were taken with a metal tape measure fixed on an aluminum bar, attached to which was a right angle which could be moved along it to the top of the child's head.

\section{Hemoglobin}

The hemoglobin values of the children were determined using the hemoglobin cyanide method. The test was undertaken directly in the field so that the result could be given directly to the mothers and sent to the health-posts in case anaemia was discovered. For this survey the rapid test method of COMPUR Medical Technology was used (Equipment: COMPUR M 1000 D1; reagent: INSTANT M, catalogue No. 6800-501). After disinfecting and pricking the fingertip the test capillary was filled horizontally with blood. Excess blood was wiped off from the capillary rim and the capillary was inserted into the cuvette. After scaling the cuvette with the adhesive label the contents were immediately mixed. After one minute the photometric measurement was taken.

\section{Parasitology}

Parasitological tests on the feces of the children were undertaken by the Central Laboratory of the Municipality Hospital of Belo Horizonte (PMBH). The feces were examined using the sedimentation technique following the description of Coulart and Costa Leite ${ }^{5}$. All feces samples were examined once only. However, $30 \%$ of the examinations (15 cases) with negative results 
were repeated. Only one sample gave a positive result on second examination.

\section{Questionnaire}

Questions on demographics, on socioeconomic and environmental characteristics, on food habits, and on the health status of the children were answered by the mothers. Auxiliary personnel were present during the enquiry by the nutritionist in order to establish an atmosphere of confidence between the interviewer and the mothers, since the nutritionist was not known in the community. The specific questions on diarrhea were developed from the suggestions arising from the WHO Diarrheal Disease Control Programme ${ }^{18}$. According to the recommendation of a WHO Working Group Meeting 20 , acute respiratory infection (ARI) was defined as being present if a child suffered from one or more of the following symptoms: blocked or runny nose, sore throat, earache or ear discharge, cough, noisy breathing, or difficult breathing.

\section{Data processing and analysis}

Data were processed on the PC (Compag II) of the Instituto de Nutrição of the Federal University of Rio de Janeiro. The anthropometric data were calculated by the Anthropometric Software Package ${ }^{7}$ which is based on the reference standard of the United States Center of Health Statistics (NCHS) following the recommendation of the WHO Working Group ${ }^{21}$. The data were transformed into weight-for-age (wt/age), heightfor-age (ht-age) and weight-for-height (wt/ ht) indices (\% of NCHS standard) to determine the degree of undernutrition (after Gomez) and to discriminate between stunting and wasting ${ }^{16}$. Furthermore, following the recommendation of the WHO Working Group 21 the distributions of the $\mathrm{ht}$ /age and $\mathrm{wt} / \mathrm{ht}$ indices related to the NCHS reference $\mathrm{Z}$-score were calculated.

The incidence of diarrhea was calculated as followed:

$\left[\frac{14 \text { days } \times \text { (No. of children) }}{1000}\right] \times\left[\begin{array}{c}\text { No. of episodes started } \\ \text { during the observed two weeks }\end{array}\right]$

The prevalence of anemia was expressed as the percentage of the surveyed population falling below the cut-off point of $11 \mathrm{~g} / \mathrm{dl}$, recommended by the WHO ${ }^{17}$ and below $9.5 \mathrm{~g} / \mathrm{dl}$ (severe anaemia). Tests of specific derived subhypotheses were carried out by a series of variance analyses with unequal sample size (one-factor ANOVA). This technique avoids the exaggerated overestimation of smaller-sized sample groups which might occur in field studies. Furthermore it enables the statistical differentiation of continuos variables, such as age groups, and also of discontinuous variables, such as the type of water supply. Missing data accounted for less than $2 \%$ of the observations for all variables with the exception of the analyses of parasites and hemoglobin, where $26.8 \%$ and $11.8 \%$, respectively, of the observations were missing.

\section{RESULTS}

\section{Socio-economic and environmental characteristics}

A total of 852 persons were living in the 140 surveyed households in the two communities, which gives an average of $6.1 \pm 2.7$ persons per household (Table 1). Although most of the households were headed by males, at least $11.4 \%$ were headed by females, where the male had left the household and the woman had not found a new partner. It was difficult to ascertain the exact number of single-headed households because it was not always possible to describe the situation in the family in cases where there still existed a loose economic connection between male and femalc. In the studied households, 267 persons (31.3\%) were children aged up to six years, an average of 2.2 preschool chidren per household. The sex ratio of the surveyed children $(53.4 \%$ males $/ 46.6 \%$ females) was almost equal. Since only families with children aged up to six years were observed, the demographic data, given in Table 1, are not necessarily representative of the whole community.

In Brazil it is common to classify the household income by the officially fixed minimum wage. During the time of the survey the official minimum wage was equivalent to US\$ 57 . An average household monthly income was said to be US\$ 148 . Only $10 \%$ of the interviewed household members had cash in hand of 230 US\$ or more. Taking into consideration the total number of household members, an average member received 25 US\$. The household income was contributed to by an average of two household members. The income situation and demographic data did not differ between the communities.

Table 2 shows the literacy and school education of the parents of the surveyed households. Around $20 \%$ of hcads of households were illiterate. Generally the females tended to have less school education than the males. Statistically there existed a high dependency between the education of fathers and mothers $(F=20.7 ; p<$ $0.00001)$.

About $70 \%$ of parents originated from outside Belo Horizonte and came from the interior 


\section{TABLE 1}

Selected characteristics of socioeconomic, housing and basic infrastructure conditions of the two urban, low income communities in "Belo Horizonte", Brazil (1986).

\begin{tabular}{|c|c|c|c|}
\hline Characteristics & "Serra" & $\begin{array}{l}\text { "Sta. Lúcia/ } \\
\text { Vila Rita" }\end{array}$ & Total \\
\hline $\begin{array}{l}\text { Surveyed families } \\
\text { Children }<6 \text { years }\end{array}$ & $\begin{array}{l}80 \\
153\end{array}$ & $\begin{array}{l}60 \\
101\end{array}$ & $\begin{array}{l}140 \\
254\end{array}$ \\
\hline $\begin{array}{l}\text { Household members: } \\
\text { Total } \\
\text { Working }\end{array}$ & $\begin{array}{l}6.1 \pm 2.7^{*} \\
1.9 \pm 1.1 *\end{array}$ & $\begin{array}{l}6.0 \pm 2.6 \\
1.8 \pm 1.1\end{array}$ & $\begin{array}{l}6.1 \pm 2.7 \\
1.9 \pm 1.1\end{array}$ \\
\hline $\begin{array}{l}\text { Household monthly } \\
\text { income (US\$) } \\
\text { Household monthly } \\
\text { income/household member } \\
\text { (US\$) }\end{array}$ & $\begin{array}{c}143 \pm 58 * \\
23.4 \pm 10.3 *\end{array}$ & $\begin{array}{c}157 \pm 68 \\
25.7 \pm 11.4\end{array}$ & $\begin{array}{c}148 \pm 64 \\
24.5 \pm 10.3\end{array}$ \\
\hline $\begin{array}{l}\text { Times of residence } \\
\text { (years) }\end{array}$ & $12.0 \pm 9.0^{*}$ & $8.5 \pm 7.3$ & $10.5 \pm 9.0$ \\
\hline $\begin{array}{l}\text { Housing conditions: } \\
\text { Brick houses }(\%) \\
\text { No. of bedrooms } \\
\text { Piped water (\%) } \\
\text { Flush toilet }(\%) \\
\text { Public removal of } \\
\text { refuse (\%) } \\
\text { Electrified }(\%)\end{array}$ & $\begin{array}{c}96.3 \\
3.2 \pm 2.0 \\
45.0 \\
26.0 \\
\\
16.3 \\
92.5\end{array}$ & $\begin{array}{c}88.3 \\
3.8 \pm 1.5 \\
76.7 \\
23.3 \\
\\
16.7 \\
98.3\end{array}$ & $\begin{array}{c}92.9 \\
3.4 \pm 1.7 \\
58.6 \\
25.0 \\
\\
16.5 \\
95.0\end{array}$ \\
\hline
\end{tabular}

* Mean and standard deviation

\section{TABLE 2}

Illiteracy and school education of the surveyed parents.

\begin{tabular}{lrrrr}
\hline \multirow{2}{*}{ Education } & \multicolumn{2}{c}{ Mothers } & \multicolumn{2}{c}{ Fathers } \\
& $(\mathrm{n})$ & $(\%)$ & \multicolumn{1}{c}{$(\mathrm{n})$} & $(\%)$ \\
\hline Illiterate & 58 & 22.1 & 47 & 17.9 \\
< 9 years school & 102 & 38.6 & 85 & 32.1 \\
9 years school & 87 & 32.9 & 94 & 35.7 \\
> 11 years school & 11 & 4.3 & 8 & 2.9 \\
11 years school & 6 & 2.1 & - & - \\
Without information & - & - & 30 & 11.4 \\
\hline
\end{tabular}

of the state of "Minas Gerais". About 25\% were from the capital itself, whereas only 5\% came from outside the federal state. The origin of one head of the household depended significantly on the other $(F=16.3 ; p<0.00001)$. Thus in general both parents were of the same geographic origin, with the exception of those who came from outside "Minas Gerais". The duration of residence of the households in the two communities averaged $10.5 \pm 9.0$ years). The settlement of the households in Serra (12.0 \pm 9.0 years) was slightly but not significantly earlier than in "Sta. Lúcia/ Vila Rita" ( $8.5 \pm 7.3$ years).

As further shown in Table 1, on average more than $90 \%$ of the houses were built with bricks or cement blocks. In Serra the availability of rooms per house was slightly lower (probably because of the higher population density of the older settlement). In Serra one room was shared by 1.9 persons, and in "Sta. Lúcia/Vila Rita" one room was shared by 1.6 persons. Nearly all the houses in the communities had electricity. However, because of the relatively high financial costs of installation, only $39.3 \%$ had received an official electrical connection from the public system, with the installation of an electricity meter. The electricity in the majority of the surveyed households (55.7\%) was supplied by their neighbors whom they paid for this "service". A significant difference between the two conurbations was with regard to water supply. Whereas in Serra only $45 \%$ of the surveyed house were connected to the public water system, $76.7 \%$ of the houses studied in Sta. Lúcia/Vila Rita had acess to the public system. Generally a very low number in either community had acess to the facilities of public waste diposal and sanitation.

\section{Magnitude of health and nutritional conditions}

According to information supplied by the mothers, only $45.2 \%$ of the children were healthy at the time of the inquiry. Acute respiratory infections (ARI) and diarrheal diseases were the 
two main morbidity problems $(34.9 \%$ and $11.5 \%$ respectively). During the preceding two weeks $21.1 \%$ of the children were said to have become infected with diarrhea, which means an estimated incidence of 17.4 episodes per 1000 child observation days. The average duration of an episode of diarrhea was associated statistically with the ht/age index $(p=0.035)$, wheres the point prevalence of diarrhea with the wt/age index $(p=0.037)$.

Besides infective diseases, a high prevalence of intestinal parasites characterized the health situation of the children.

According to Table 5, children who suffered from intestinal parasites had a significantly lower wt/age index than those with a negative result $(\mathrm{F}=4.39 ; \mathrm{p}=0.039)$.

The hemoglobin level was also observed to help assess the state of health of the children (Table 3). On the basis of a cut-off point of $\mathrm{Hb}<$ $11 \mathrm{~g} / \mathrm{dl}$, about one third of the children of Serra and one fourth of Sta.Lúcia/Vila Rita were suffering from anemia. Determinants of the risk of anemia were household income per family member, the origin of the father, the type of electricity supply, and the type of the first food given to the children (Table 5). Those children who recieved fruit as a dietary supplement had a significantly higher hemoglobin level than the others $(p=0.002)$.
The mean weight and height of the children aged up to six years are shown in Figure 1. In general the weight in the first three age groups was close to the standard weights of the NCHS reference population. The weights from the age group of 10-12 months were lower $(-0.5 \mathrm{~kg})$ than that of the age group of 7-9 months. The height of the age groups up to 6 months corresponded closely to the NCHS curve (on average down to around $95 \%$ of the height of the reference population). Wt/age and ht/age indices were statistically better during the first year of life $(p=0.032$ and $p=0.010$ ) than during the rest of the observed period. This trend could be observed in both communities.

Considering the wt/age distrilbution of all surveyed children with reference to the Gomez classification, about $50 \%$ had normal weight for their age. Yet only $8.2 \%$ of the children of Serra and $7.2 \%$ of the children of "Sta. Lúcia/Vila Rita" can be considered as moderately or severely malnourished. On the basis of the Waterlow classification, it can be stated that the main problem in the communities was stunting, whereas wasting was minor problem (Table 4, Figure 2).

\section{Contributary factors}

According to Table 5, the school education of the mother was a crucial determinant in all anthropometric data. The less school education the

\section{TABLE 3}

Prevalence of anemia in children of the two communities studied

\begin{tabular}{lcccccr}
\hline Prevalence & \multicolumn{2}{c}{ "Serra" } & \multicolumn{2}{c}{$\begin{array}{c}\text { "Sta. Lúcial } \\
\text { Vila Rita" }\end{array}$} & \multicolumn{3}{c}{ Total } \\
& $(\mathrm{n})$ & $(\%)$ & $(\mathrm{n})$ & $(\%)$ & $(\mathrm{n})$ & $(\%)$ \\
\hline $\begin{array}{l}\text { Anemia } \\
(\mathrm{Hb}<11 \mathrm{~g} / \mathrm{d})\end{array}$ & 48 & 33.8 & 19 & 23.2 & 67 & 29.9 \\
$\begin{array}{l}\text { Severe anemia } \\
(\mathrm{Hb}<9.5 \mathrm{~g} / \mathrm{d})\end{array}$ & 20 & 14.1 & 4 & 4.9 & 24 & 10.7 \\
Total children & 142 & 100.0 & 82 & 100.0 & 224 & 100.0 \\
\hline
\end{tabular}

mother had recieved, the worse were the anthropometric indicators of the nutritional status of the children. Furthermore, in the case of wt/ht index, the children of mothers who originated from the interior or from outside the state of "Minas Gerais", ran a greater risk of wasting than those from the capital $(p=0.022)$. The type of electricity supply was likewise a risk factor for a low ht/age index. Families who owned an electricity meter and received their electricity supply directly from the distributing light company had far fewer stunded children than those who were subtenants and dependeci on the supply from other households ( $\mathrm{p}<0.00001)$.

\section{DISCUSSION}

In contrast to the two metropolitan centers "São Paulo" and "Rio de Janeiro"4, where a notable proportion of the favela (shantytowns) population is composed of migrants from the deprived northeast region of Brazil, and where sometimes whole neighborhoods from the same 


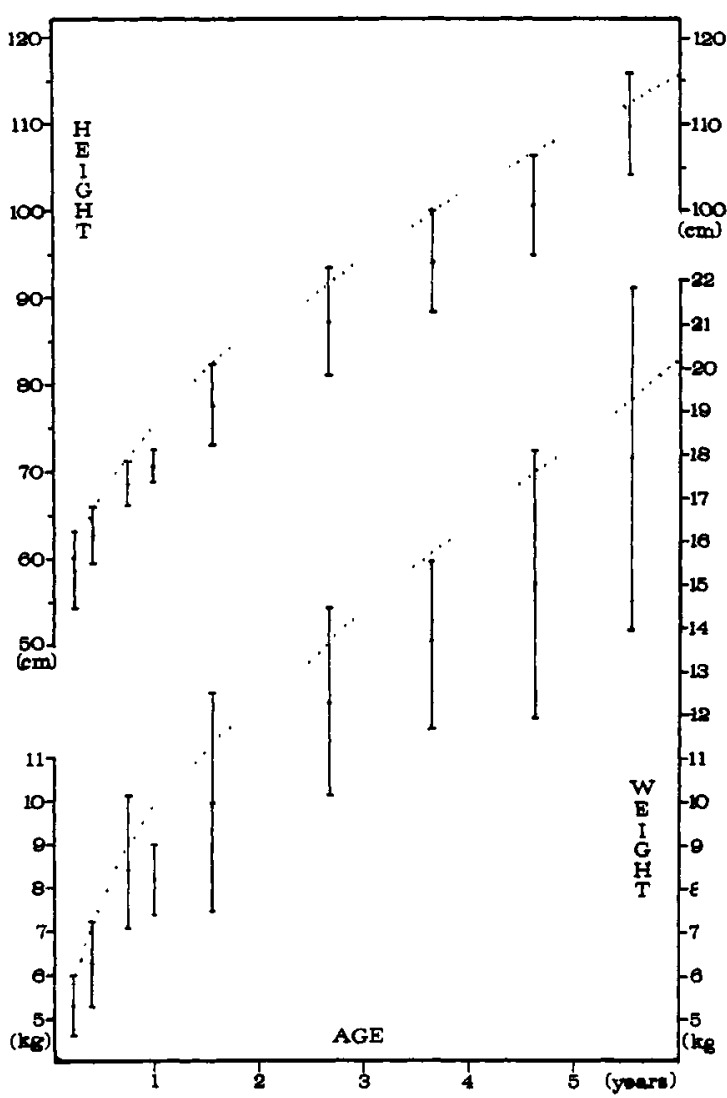

Fig. 1 - Mean ( \pm S. D.) weight and height by age groups in both urban communities of Belo Horizonte $(n=253)$ compared with the mean of normalized NCHS/CDC anthropometric reference height and weight for age (Jordan 8).

viliages are transplanted, the population of the two observed communities are mainly mineiros*. Therefore the socio- cultural heterogeneity is far lesse than in the metropolitan areas of "São Paulo" or "Rio de Janeiro".

In "Sta. Lúcia/Vila Rita" there were slightly fewer solid house than in "Serra". This might be because the first community was established more recently. It is common to settle first in houses constructed from less solid materials such as wood, sheet metal and cardboard. Later on, more and more parts of the houses are replaced by bricks and other solid construction materials.

Generally the households can be divided into the better school-educated families who moved within Belo Horizonte to one of the two communities and the less educated rural migrants from the interior.

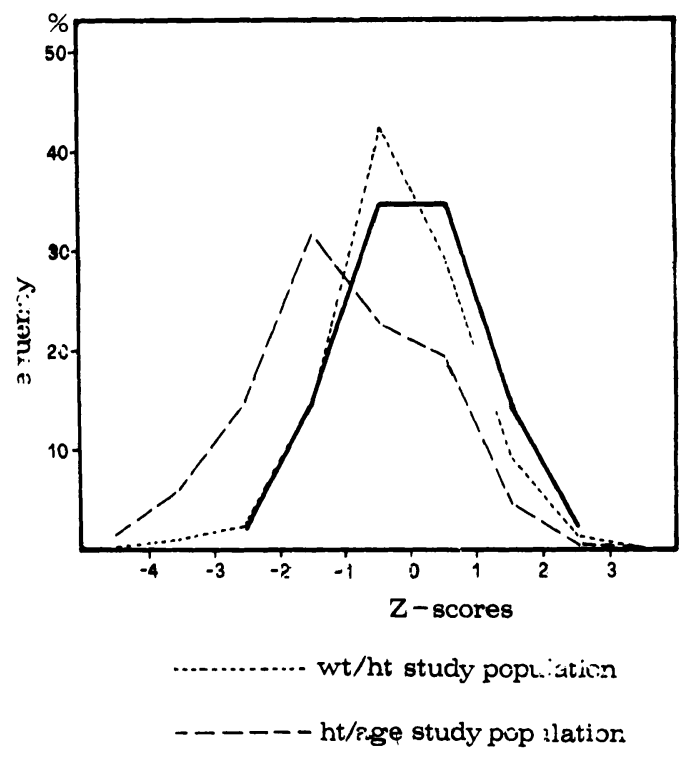

Fig. 2 - Distribution curves of wt/ht and ht/age of the studied children in relation to the NCHS reference Z-score.

The income situation of the households did not significantly influence the anthropometric data of the children. It seems that the cultural background in the community has a much highor effect on the nutritional status than the economic situation. Monteiro et al. ${ }^{11}$ and Victora et al. ${ }^{14}$ have demonstrated that the low income of families of different Brazilian communities is an important risk factor for malnutrition. However, within an urban community income plays a much less important role than other socioeconomic variables such as school education and provenance of the parents. The same observation was made in another urban slum population in South America ${ }^{15}$. This may be due to three factors:

- household members are not willing and/or are not able to give accurate information about the family income,

- there is not sufficent statistical variability to find a significant association between nutritional status and family income,

- within the community other factors such as environment (water supply, sanitation facilities, health service, etc.) or even education and cultural background play a more important role.

On the other hand the income situation had an impact on anemia. Children originating from poor households showed a significantly higher risk of anemia than those of better-off families. 


\section{TABLE 4}

Distribuition of malnourished children in the two urban areas expressed by the Gomez classification (wt/age deficiency: moderate and severe malnutrition; cut-off point: $<75 \%$ ) and by the Waterlow classification (ht/age deficiency: stunting; cut-off point: < 90\%) - wt/ht deficiency: wasting; cut-off point: <80\%).

\begin{tabular}{|c|c|c|c|c|c|c|}
\hline \multirow{2}{*}{$\begin{array}{l}\text { Pravalence of } \\
\text { malnutrition }\end{array}$} & \multicolumn{2}{|c|}{ "Serra" } & \multicolumn{2}{|c|}{$\begin{array}{l}\text { "Sta. Lúcia/ } \\
\text { Vila Rita" }\end{array}$} & \multicolumn{2}{|c|}{ Total } \\
\hline & (n) & (\%) & $(\mathrm{n})$ & $(\%)$ & (n) & $(\%)$ \\
\hline $\begin{array}{l}\text { Moderate and severe } \\
\text { malnutrition }\end{array}$ & 12 & 82 & 5 & 5.3 & $\nabla$ & 7.1 \\
\hline Stunting & 16 & 11.0 & B & 13.7 & 29 & 12.0 \\
\hline Wasting & 5 & 3.4 & 1 & 1.1 & 6 & 3.1 \\
\hline $\begin{array}{l}\text { Stunting and } \\
\text { wasting }\end{array}$ & 1 & 0.7 & 0 & 0.0 & 1 & 0.4 \\
\hline Total Children & 146 & 100.0 & 95 & 100.0 & 241 & 100.0 \\
\hline
\end{tabular}

\section{TABLE 5}

Statistical significance of socioeconomic, demographic and experimental effects on selected experimental effects (one-factor ANOVA; F-values and level of significance).

\begin{tabular}{|c|c|c|c|c|c|}
\hline Main effect & DF & $\begin{array}{l}\text { Anthr } \\
\text { wt/age }\end{array}$ & $\begin{array}{l}\text { etric } \\
\text { ht/age }\end{array}$ & $\begin{array}{c}\text { parameters } \\
\text { wt } / \text { ht }\end{array}$ & Hemoglobin \\
\hline Age of children & 5 & $3.10^{*}$ & $2.43^{*}$ & 0.37 & 0.62 \\
\hline Sex of children & 1 & 2.12 & 0.51 & 0.89 & 3.32 \\
\hline $\begin{array}{l}\text { No. of siblings } \\
\text { Household income/ }\end{array}$ & 2 & 0.31 & 0.89 & 0.06 & 0.43 \\
\hline $\begin{array}{l}\text { family member } \\
\text { School education }\end{array}$ & 4 & 0.21 & 0.60 & 0.41 & $2.57^{*}$ \\
\hline father & 3 & 1.18 & 2.47 & 0.20 & 0.58 \\
\hline mother & 3 & $4.63^{* * *}$ & $4.04^{* *}$ & 2.36 & 0.78 \\
\hline Origin of father & 2 & 1.18 & 2.27 & 0.07 & $2.93^{*}$ \\
\hline mother & 2 & 0.21 & 1.71 & $3.62^{*}$ & 1.52 \\
\hline Time of residence & 4 & 1.73 & 1.10 & 1.83 & 0.73 \\
\hline Persons/bedroom & 4 & 0.81 & 0.58 & 0.61 & 1.10 \\
\hline Water supply & 3 & 0.31 & 0.98 & 0.09 & 0.33 \\
\hline Sewage facilities & 3 & 0.31 & 0.85 & 0.68 & 0.79 \\
\hline $\begin{array}{l}\text { Refuse removal } \\
\text { Electricity }\end{array}$ & 4 & 0.66 & 0.40 & 2.05 & 1.30 \\
\hline supply & 2 & 2.44 & $5.32^{* * *}$ & 0.43 & $6.36^{* *}$ \\
\hline Parasites & $\overline{1}$ & $4.39^{*}$ & 1.53 & 2.38 & 0.38 \\
\hline Diarrhea duration & 5 & 1.13 & $2.08^{*}$ & 0.98 & 0.98 \\
\hline incidence & 1 & 0.21 & 0.06 & 0.35 & 0.54 \\
\hline point prevalence & 1 & $4.42^{*}$ & 2.74 & 1.91 & 1.37 \\
\hline Study area & 5 & 0.59 & 0.49 & 0.66 & 0.99 \\
\hline
\end{tabular}

\footnotetext{
Significance level:$$
p<0.05
$$$$
\text { ** } \quad \mathrm{p}<0.01
$$$$
\text { *** } \quad \mathrm{p}<0.001
$$ 
This fact might be due to the fact that children of low-income families received their proteins mainly from the government- subsidized cow's milk and eat less expensive meat or legume proteins.

The surveyed children suffered from a high prevalence of infectious diseases. The incidence of diarrhea in this study is consistent with the data given from another survey of urban, lowincome-group children in Peru ${ }^{8}$.

Another health problem was the high prevalence of anemia. This was found of a lesser order in another preschool child population of low-income families in "Belo Horizonte" 1 and the same as in the preschool child population of "São Paulo"10. In both studies intestinal parasitosis was not identified as being responsible for the lower hemoglobin level.

Considering the anthropometric data of the children of the two communities it is striking that during the first months of life weight and height are identical to the North American population of NCHS. Only with advancing age do anthropometric characteristics start to alter. The interruption in the wt/age index development of the 10-12-months-old infants can hardly be explained by weaning problems because after six months of age $60 \%$ of the children have already been weaned and of the remainder only $5 \%$ are receiving breast milk exclusively.

The proportion of stunted children increased continuously after the first half year of life. Although the wt/ht index decrease too, wasting played only a minor role. This fact has been observed recently in children of other lowincome urban communities in Brazil 6,11 as well as in other Latin American countries ${ }^{8}$. This slowing of growth, which occurred only after the first months of life, is due to external factors such as diet and/or infectious diseases. Several studies have demonstrated that stunting can be associated with diarrhea morbidity ${ }^{13}$. From the high prevalence of diarrhea morbidity in this surveyed population, one can infer that diarrhea was one of the contributory factors which slowed growth. The statistical analysis shown in Table 5 demonstrates that stunting here is not associated with a high incidence of diarrhea, but rather with a prolonged duration of diarrhea. This observation has already been made by Black et al. 2 . In particular, the age group from 9 months to two years suffered from a high diarrhea morbidity rate and a significantly lower height.

Point prevalence of diarrhea was associated with the wt/age index but not with the rest of the observed anthropometric indicators. Wt/age represents the sum of the information given by the other two indices, ht/age and $\mathrm{wt} / \mathrm{ht}$ respectively 21 . The slightly lower ratio of these indices in children with diarrhea led to a significantly lower wt/age index in the case of point prevalence but not in the case of period prevalence. This difference may be due to the fact that mothers tend to underestimate the duration of a diarrheal episode. Furthermore it should be kept in mind that the estimated period prevalence is based only on the extrapolation of a two-week result.

Moreover the wt/age index was statistically associated with intestinal parasitosis. Children who suffered from parasitosis had a slightly but not singficantly lower weight and height relative to their age.

The precarious health situation of the children with regard to infectious diseases indicates that the nutritional situation of these urban children is exacerbated by their deficiente health status, which is mainly due to the poor sanitation and medical facilities observed in these communities.

MOLINA, M.C.B. et al. Estado nutricional de crianças de comunidades de baixa renda, Brasil, 1986. Rev.Saúde públ., Săo Paulo, 23:89-97,1989.

RESUMO: Foi analisado, em 1986, o estado nutricional e de saúde de 254 crianças de idade inferior a seis anos, procedentes de duas favelas da cidade de Belo Horizonte, Brasil, e estudada a situação sócio-econômica dos seus pais. O estado nutricional das crianças foi caracterizado em função da redução do crescimento ( $Z$-score: $20,1 \%<-2$ ) e näo em função da perda de peso ( $Z$-score: $3,7<-2$ ). Pesquisou-se até que ponto a causa da redução do crescimento se deve à elevada taxa de morbidade, como por exemplo infecçōes respiratórias agudas (taxa de prevalência: 38,5\%), doenças diarréicas (taxa de prevalência: $11,5 \%$ ) e parasitoses (taxa de prevalência: $70,3 \%$ ). Também a anemia (taxa de prevalência: $29,7 \%$ ) foi considerada como um outro problema de saúde. Quanto à prática do aleitamento materno verificou-se uma prematura suplementação dietética. A partir dos 3 meses de idade apenas $50 \%$ das crianças eram amamentadas, das quais so $20 \%$ o eram exclusivamente com leite materno. A introdução escolar das mães constituiu a determinante mais importante dos índices antropométricos. Este fator e a origem dos pais determinou o padräo de aleitamento materno. Os resultados permitiram concluir que o estado nutricional das crianças deve-se ao precário estado de saúde e não propriamente à falta de alimentos.

DESCRITORES: Estado nutricional. Nível de saúde. Antropometria. Crescimento. Morbidade. 


\section{REFERENCES}

1. ARAUJO, R.L et al. Evaluation of a program to overcome vitamin $A$ and iron dificiencies in areas of poverty in Minas Gerais, Brazil. Arch. Latinoamer. Nutr., 47: 9-22, 1987.

2. BLACK, R.E. et al. Malnutrition is a determining factor in diartheal duration, but not incidence, among young children in a longitudinal study in rural Bangladesh. Amer. J.clin Nutr.,37: 87-94, 1984.

3. FOX, R.W. The urban explosion. Nat.Geogr., 166: 179 $85,1984$.

4. FUNDAÇÃO INSTITUTO BRASILEIRO DE GEOGRAFIA E ESTATISTICA (IBGE). Anúario Estatístico do Brasil - 1983. Rio de Janeiro, 1983.

5. GOULART, E.G. \& COSTA LEITE, I. Moraes parasitologia \& microbiologia humana. $2^{4}$ ed. Rio de Janeiro, Ed. Cultura Médica, 1978.

6. GROSS, R. et al. The influence of economic deterioration in Brazil on the nutritional status of children in Rio de Janeiro, Brazil. Ecol. Food Nutr., 19: 265-79, 1987.

7. JORDAN, M.D. Anthropometric software package. Atlanta, Georgia, U.S. Department of Health and Human Services/Public Health Service/Centers of Disease Control, 1986.

8. LOPEZ DE ROMANA, G. et al. Health and growth of infants and young children in Huśscar, Pení. Ecol.Food Nutr., 19: 213-29, 1987.

9. MONTEIRO, C.A. Urbanization, health and nutrition in developing countries. In: Gross, R. \& Solomons, N.W., eds. Tropical urban nutrition. Eschborn, Deutsche Gesellschaft für Technische Zusammenarbeit GTZ, 1987. p. 61-77. (Sonderpublikation GTZ, $n^{2}$ 197).

10. MONTETRO, C.A. \& SZARFARC, S.C. Estudo das condiçżes de saúde das crianças do Município de São Paulo, SP (Brasil), 1984-1985. V - Anemia. Rev. Saúde públ., S.Paulo, 21: 255-60, 1987.

11. MONTEIRO, C.A. et al. Estudo das condições de saúde das crianças do município de São Paulo, SP (Brasil), 1984-
1985. II - Antropometria nutricional. Rev. Sauide públ., S.Paulo, 20: 446-53, 1986.

12. SOLOMONS, N.W. \& GROSS, R. Urban nutrition in the tropics: a new paradigm in international health. Food Nutr.Bull., 9, 43-4, 1987.

13. TROWBRIDGE, F.L. Wasting and stunting as risk factors for morbidity and mortality. In: Taylor, T.G. \& Jenkins, N. K., eds. Proceedings of the XIII International Congress of Nutrition, 1985. London, John Libbey, 1986. p. $93-6$

14. VICTORA, C. et al. Risk factors for malnutrition in Brazilian children: the role of social and environmental variables. Bull. Wld Hlth Org., 64: 299-309, 1986.

15. WALTER, J.P. Two poverties equal one hunger. $J$. Nutr Educ., 5: 129-33, 1973.

16. WATERLOW, J.C. Cassification and definition of proteincalorie malnutrition. Brit.med.J., 3:566-9, 1972.

17. WORLD HEALTH ORGANIZATION. Scientific Group on Nutritional Anaemias, Geneva, 1967. Report. Geneva, 1968. (Technical Report Series, 405).

18. WORLD HEALTH ORGANIZATION. Development of indicators for monitoring progress towards health for all by the year 2000 . Genevs, 1981.

19. WORLD HEALTH ORGANZATION. Measuring change in nutritional status. Geneva, 1983.

20. WORLD HEALTH ORGANIZATION. Case management of acute respiratory infections in children in developing countries; report of a working group meeting. Geneva, 1986. (WHO/RSD/85.15 Rev. 2).

21. WORLD HEALTH ORGANIZATION. Working Group. Use and interpretation of anthropometric indicators of nutritional status. Bull. WHO, 64: 929-41, 1986.

Received in 28/4/1988 Reviewed in 10/11/1989 Accepted in 12/1/1989 